\title{
THE ENGLISH SCANNING SKILLS OF BILINGUAL AND MONOLINGUAL INDONESIAN STUDENTS
}

\author{
Anna Marietta da Silva \\ Atma Jaya Catholic University of Indonesia \\ email: anna.silva@atmajaya.ac.id
}

\begin{abstract}
Studying the reading competence of Indonesian EFL within the framework of bilingualism can be challenging for language researchers. That may be because the area has not yet deeply explored by Indonesian researchers, while Indonesia provides a vast array of data due to its diverse linguistic background. The present small study investigates the English scanning skills of forty-three Indonesian EFL primary level students. Forty nine percent of the subjects are monolinguals, i.e. they use only Indonesian both at home and school. The rest are bilinguals: they use Indonesian and local languages interchangeably at home. The result of the study shows that in general the Indonesian monolinguals have a better performance in comparison to their bilingual counterparts.
\end{abstract}

Keywords: bilingualism, scanning skills, reading comprehension

\section{KETERAMPILAN MELAKUKAN SCANNING DALAM BAHASA INGGRIS PARA SISWA INDONESIA BERDWIBAHASA DAN BEREKABAHASA}

\begin{abstract}
Abstrak: Kemampuan membaca dalam Bahasa Inggris dari para siswa Indonesia dalam kerangka kedwibahasaan cukup menantang untuk diteliti oleh para peneliti bahasa. Hal tersebut terjadi karena masih kurang didalaminya bidang penelitian kedwibahasaan di Indonesia, terutama yang berkaitan dengan kompetensi berbahasa Inggris. Padahal, Indonesia dengan latar belakang linguistik yang begitu beragam merupakan lahan subur untuk penelitian di bidang tersebut. Penelitian kecil ini berfokus pada kemampuan scanning dalam Bahasa Inggris dari empatpuluh tiga siswa sekolah dasar. Empat puluh sembilan persen dari subyek penelitian ini berbahasa tunggal, yaitu Bahasa Indonesia di rumah dan di sekolah, dan sisanya berbahasa Indonesia di sekolah dan berbahasa daerah di rumahnya. Hasil penelitian menunjukkan bahwa secara umum hasil tes kemampuan scanning siswa yang hanya berbahasa Indonesia mengungguli siswa yang berdwibahasa.
\end{abstract}

Katakunci: kedwibahasaan, scanning, pemahaman bacaan

By and large, Indonesian young generations nowadays are more exposed to English than their parents or grandparents. Indonesian first graders of primary schools, especially those living in big cities, are now learning English at least once a week within around fifty to sixty minutes per session. Even kindergarten pupils have started learning simple vocabularies of English at schools, which can be related to a common belief that the younger a child learns an additional language, the easier it is for her/him to grasp, and eventually use the new language (Zacharias 2010, pp. 75, 58). Besides that, today's youngsters see more English texts around them, e.g. advertisements in billboards, newspapers, magazines and internet, mobile phones, smart phones, and hear more English programs broadcasted by the national and foreign private TV stations or channels. In 
addition, they witness that more and more English speakers, who are members of the 320-380 million speakers English speech community in USA, UK, Ireland, Canada, Australia and New Zealand, (Crystal 2003, pp. 60-61) come to Indonesia for a temporary visit or permanent stay for a lot of purposes, primarily for business. Moreover, the youths experience another more common linguistic fact: the mixed use of Indonesian and English on teen magazines such as Cosmogirl, Gadis, and Hai. Research on code-mixing in one of the magazines, i.e. Hai showed that of 106 articles there were 1334 instances of codemixing, in which the journalists or writers mostly code-switched nouns, and did it to serve several functions from referential function to expressing emotion and wanting to be part of the global community (Rafiani 2009). In addition, it is common for youngsters to code-switch from Indonesian to English spontaneously when talking to their friends, chatting through their e-mail account, Facebook or Twitter without following a fixed pattern (Wiradisastra 2006). Hence, Indonesia belongs to the expanding circle (Kachru 2011, p.155).

Technology development has made it possible to have rapid contact of languages. Yet, not all languages in contact will be necessarily learned. Language speakers do select which language is to learn, and which is not. The fact that English is probably the most popular foreign language learned in Indonesia may be due to several reasons: 'economic and trade,' easy access to information mostly printed in English, or tourism (Baker 2001, pp.111-112), and Indonesian speakers' positive attitude towards English (Heaney 2005; Siregar 2010). Henceforth, English is more acceptable for advertisements, features of national TV programs, or titles of features in popular magazines, for instance, in comparison to other foreign languages. The other factor is the parents' ambition to see their children to win the competition within the job market in the future. A lot of parents have sent their children to English courses and bilingual schools to help them get good English grades at school and a lot of exposures to English (Djiwandono 2005; Sari 2010).

However, there does not seem to be any parallel relationship between the increasing contact with English and the Indonesian students' English competence, specifically in terms of their reading skills (Nurkamto 2003, pp.288, 294-295). That can be due to several factors such as the status of English as a foreign language; cultural values, lack of learning facilities; teacher's incompetence, and ineffective assessment system, all of which might lead to the very rare use of the English language (Nurkamto 2003, pp.295, 297, 300; Djiwandono 2009, p.3). In addition, most families in Indonesia do not communicate using English (Zacharias 2010, p.76). They use Indonesian and or one or several local languages at home. Very seldom do Indonesians use English.

To make the problem more complicated, reading (and writing), which has been part of the English culture, is absent from the cultures of most ethnic groups in Indonesia. As values and norms were passed from one to another generation by means of oral communication, it is not the custom for most if not all of the ethnic groups to write the histories of their ancestors, and read it to their children, grand-children, and great grand-children. As a result, reading and writing are not the habit and need of most families in Indonesia, especially those living in rural areas. In that case, economic status may contribute to a certain extent to the need of reading and writing. Thus, English teachers often complain about their students' low reading interest, even for novels or stories outside schools for fun (Progress in International Reading Literacy Study 2006, pp.141, $146,152,155)$, which in turn creates typical problems for the Indonesians learning English reading skills. 
Now that English is taught since the primary level, I wonder how the increasing contact with English will affect the reading skills of the young learners. Hence, this preliminary research is aimed at finding out the access of Indonesian learners to English, and the comparison of the Indonesian bilingual and monolingual students' performance on the English reading skills, particularly the scanning skills.

\section{What does it Take to be a Bilingual?}

A bilingual may not simply indicate an ability to speak two languages. Factually, a number of research conducted by many scholars have even led to the complexity of defining the phenomenon. Thus, a bilingual may encompass one's language competence, performance, or both the competence and performance. Discussing the cases of immigrant children living in English-speaking countries, Bloomfield (1935, pp.55-56) states that the children can be called bilinguals if they retain their native or first languages while learning a second language, English for instance, to an extent that they have "... a native-like control of two languages." In that case, a Javanese, whose first language is Javanese and second language is Indonesian, speaking Indonesian with a heavy Javanese accent cannot be classified into a bilingual. Sharing almost the same opinion, Weinreich $(1963, \mathrm{p} .1)$ notes that a bilingual is able to switch from one language to another smoothly. Yet, such circumstance is only possible when one has a lot of exposures to the two languages, a condition of which will make him able to speak the languages interchangeably. Grosjean (2010, pp.4, 22) seems to support Weinreich; he suggests that bilinguals are ". . . those who use two or more languages (or dialects) in their everyday lives." He further states that the definition puts a heavy emphasis on someone's performance in terms of two or more languages and dialects. He believes that one cannot neglect the many circumstances leading to bilingualism include interaction among people of different languages for various purposes: trade, power expansion, religious missionary, marriages, change in economic status and creation of a sign language for the deaf people (Grosjean 2010, pp. 5, 8-13). All of which results in language contact, or termed as 'interference phenomena' by Weinreich (1963, p.1). Those are some among many other factors that encourage one to acquire or learn more than one language.

Nevertheless, it seems that the notion of bilingualism does not only cover the language performance and competence. A different highlight comes from Hamers and Blanc (2000, p.6) who point out about bilingualism and bilinguality. While the former indicates a specific milieu whose members speak more than two languages to serve various purposes, the latter signifies one's cognitive 'access' to two different languages to serve a number of communication purposes. Yet, " . . the degree of access will vary along a number of dimensions which are psychological, cognitive, psycholinguistic, social psychological, social, sociological, sociolinguistic, sociocultural and linguistic". Thus, both scholars emphasize on how languages make contact, its influence and implications to the society consisting of many different ethnic groups. Similarly, Bialystok (2003, pp. 26) gives some illustrations on how complex to define a bilingual person due to the increasing contact of languages, which in turn makes it even harder to address one as monolinguals. The complexity might be because bilingualism lies on a spectrum from an individual learning a second language to a nation having two languages at use.

Defining bilingualism is even becomes more complicated when language proficiency is taken into account as there are some features of language that may not be universal, for example the absence of the concept of word in 
Chinese, as opposite to English, or in a case of one may be competent in one or two language skills of the second language, but may not be so in all or other skills, for instance one may be a good reader, but not a good speaker, which may be due to different purposes of learning the skills (Romaine 1995, p. 13). In addition, there is still a debate of what constitutes a language; one may call a dialect a language, while others will not. One more determinant factor is the attitude of the speaker to the languages which will determine his choice of admitting, appreciating and using one language over another. This study adopts the term bilingual as proposed by Grosjean (2010, pp.4, 22).

\section{English Reading Skills}

Reading can be defined as an activity in which a reader connects him/herself to a writer by means of the meaning of a text (Clarke \& Silberstein 1979, p.50; Nuttall 1996, pp.1, 4; Underwood \&Batt 1996, p.2; Hudson 2007, p.33; Grabe 2009, p.15). However, reading cannot be simply identified because one may not be able to explain how he or she is able to read or understand the message of a text after reading it due to the complexity involved in the reading activity (Grabe 2009, p.14). Thus, reading can mean either a "... rapid and efficient process ..." because of the high speed and very short-term goal a reader wants to achieve through reading; a “. . . comprehending process ..." as one intends to understand the meaning or message that is conveyed in the text; or a “. . . purposeful process ..." since a reader usually reads for some purposes (Grabe 2009, pp.14-15). Consequently, reading serves a number of purposes from searching to learning to evaluating or criticizing things (Grabe\&Stoller 2002, pp.13-14; Grabe 2009, pp.7-10).

To be a good reader, one needs to employ the reading skills. According to Munby, who proposed a typology of language skills, reading skills are considered to be macro-concepts (1978, pp.116, 122, 123-131) consisting of several skills, one of which is the scanning skill. Scanning is carried out within a short period of time, and becomes a step toward a further and deeper reading activity (Nuttall 1996, p. 49; Grabe 2009, p.8). In other words, scanning is the basic skill of reading and a. Thus, scanning is usually learned first in EFL reading classes. Scanning is a type of reading skills that is characterized by activities of searching a specific information in a text (Clarke \& Silberstein 1979, pp.51; Rosenshine 1980 as cited in Hudson 2007, pp.80-81; Grabe \& Stoller 2002, p.13; Nation 2009, p.70). The examples of scanning tasks can range from searching for one's name, specific date, number, place, or particular words (Clarke \& Silberstein 1979, p.55; Nuttal 1996, p.49; Grabe and Stoller 2002, p.13; Nation 2009, p.70).Scanning can help a reader to choose which text he or she would like to read and to become efficient reader who select reading materials to serve his/her reading purpose (Nuttall 1996, p.44; Grabe 2009, pp.14, 15).

\section{Bilinguals' and Monolinguals' Reading Skills: Previous Studies}

In this session, I will briefly describe previous research done on bilingualism and the reading skills competence. Ridley (2005) studied the reading scores of kindergarten students who joined the immersion program between Spanish students learning English and those learning English as a first language. She analyzed students' scores on several standardized tests such as ITBS, TAKS, Logramos, Stanford 9, and Aprenda. She wanted to find out whether there was an effect of students attending an immersion program compared to those in regular/bilingual schools in terms of their reading scores. Her study showed that there is no significant difference between the two groups. Both groups were able to pass the standardized tests at the passing level. She noted that there was an 
advantage students of the immersion program got, i.e. they were facilitated to become bilingual as the native speakers of English could learn Spanish, and the Spanish students could learn English.

Toloa, McNaughton, and Mei (2009) conducted a longitudinal study on the relationship between L1and L2 reading comprehensions at seven urban bilingual primary schools in New Zealand where Samoan and English were used interchangeably. The participants of the research consisted of two groups: the Samoan-English bilinguals and the Samoan mainstreams. The use of the Samoan and English languages varied, depending upon the curriculum and needs. All reading texts used for teaching reading comprehension, however, were in English. The tests employed were Elley's Supplementary Tests of Achievement in Reading (STAR) for English reading comprehension. Their research showed that there was a positive correlation between $\mathrm{L} 2$ reading comprehension and L1 reading comprehension, which suggested the possibility of transfer from $\mathrm{L} 2$ to $\mathrm{L} 1$ in reading comprehension.

Aquino's study (2012) on the effect of language instruction to literacy of monolingual Filipino, monolingual English and bilingual preschoolers showed that the children's literacy skills who received either Filipino or English monolingual instruction were better than those who had both instruction in English and Filipino.

Earlier studies revealed that in terms of reading skills bilinguals may not always outperform the monolinguals in terms of learning English. There can even be a positive transfer of $\mathrm{L} 1$ reading skills to that of the L2. Of the aforementioned earlier studies, none has focused specifically on scanning competence of Indonesian EFL primary students whose language background can vary. As a matter of fact, scanning is one of the basic reading skills which is also part of the English achievement test given in the formative or achievement test. Thus, it is relevant to conduct a small study on the scanning competence of bilingual and non-bilingual Indonesian primary level students. The study may fill the lack of studies on the role of bilingualism in developing English reading skills, particularly the scanning skill.

\section{METHOD}

The study took place at school X, a private national school in East Jakarta on October 2 and 9, 2012. In that school, Indonesian is used as the language of instruction. Subjects of the research were 43 students of grade 6 . They came from diverse ethnic groups: Bataknese, Central Javanese, Sundanese, Niasnese, Sulawesinese, Manadonese, and Chinese. Their ages were between 10 to 12 years old; ten students were 10 years old, thirty were 11 years old, and 3 were 12 years old (vide Fig. 1). Of the pupils, $51 \%$ were girls, and $49 \%$ were monolinguals. Convenient sampling was used for this research due to time and financial restrictions.

A small survey consisting of openended questions in Indonesian language (vide Appendix 1) about the subjects' identities and language backgrounds was conducted on October 2, 2012. As the subjects were $6^{\text {th }}$ graders, whom I assumed would not be capable of completing such a complicated questionnaire like that of Baker's (1992, pp.138-151), or the Likert scale, and due to some limitations such questionnaire has (Turner 1993; Busch 1993) I made open-ended questions that would inform me of the subjects' language background and contact with English, along with their attitude towards English. Yet, the questions I made were based on the some of the questions given on measuring language and attitude (Baker 1992, pp141-143). All of the subjects then joined a test of scanning skill that I gave on October 9, 2012. Because there has not been any standardized test of English as a local content subject for Indonesian primary students, and the primary 
objective of English learning at the school is a mastery of grammar and vocabulary relevant to the textbook used (a short personal interview with $\mathrm{S}$, the English teacher of school X, on September 27, 2012), I took Weir's sample of scanning test (1993, pp.82-83, 85-86); (vide Appendix 2). To check my understanding of the information I got from S, I also observed the textbook used by the students (title: Fly with English, author: Frances Bates-Treloar and Steve Thompson, publishing house: Marshall Cavendish Education).

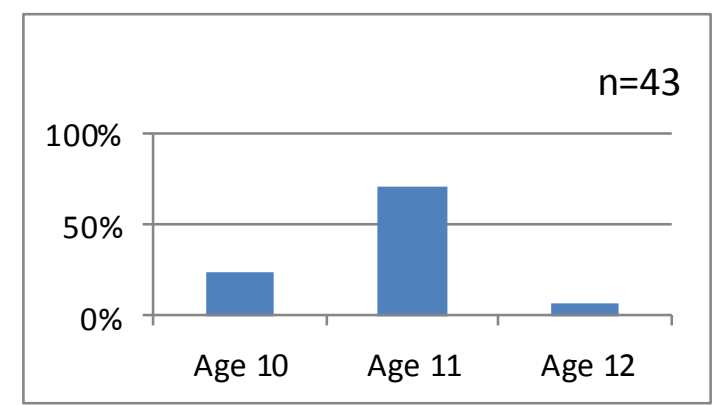

Fig. 1 Graph of student's age

The following is the description of the test. It consisted of two parts. In the first part I had a text about short histories of five people's job: their previous and present jobs, how long they have been in their recent jobs, and reasons for choosing the latest jobs (vide Appendix 2). Following the text was an incomplete table consisting of five columns and five rows. The first column, entitled Name, consisted of the names of the people in the text. The second column, entitled Job before, required the participants to fill in with the five people's previous jobs. The third column, labeled Job now, was to be filled with the five persons' present jobs. The fourth column, titled Years, should state the number of years each person has spent for the present job. The fifth column, labeled Why in job, required the students to write each person's reason for choosing their last job. One example was given for each column so that the participants had a specific guide that would help them connect each of the title of the column with the specific information available in the text. Making the best use of the examples, students were expected to be able to find particular information in the text to fill in to the appropriate column.

The second part contained a text about the description of Saudi Arabia (vide Appendix 2). I chose Saudi Arabia because of an assumption that the subjects must have been accustomed to the Moslem milieu, including the very close bilateral and historical relationship between Indonesia and Saudi Arabia, the pilgrimage to Mecca and Medina made by Moslems around the subjects, the widely known exported product from Saudi Arabia like oil and dates, and news about Saudi Arabia in connection to Indonesia. Following the text was an incomplete form into which participants had to write specific information about Saudi Arabia: its capital city, area, head of state, official religion, language, currency used, holy places, exports, climate, and average yearly rain fall on spaces provided. All in all, the test required participants to find specific information concerning people's jobs, and a general description of a country.

\section{FINDINGS AND DISCUSSION}

In this part I will describe the survey of the participants' language background, followed by their contact with and attitude towards English, and finally by the test results. The survey reveals the variety of languages used by the subjects within their surroundings. The monolinguals (49\%) use only Betawi-Malay (BetawineseIndonesian) in daily communication with people around them: their nuclear and extended families, friends, and teachers. The bilinguals $(51 \%)$ comprise speakers of other ethnic languages in addition to the Betawi-Malay. Of the bilinguals 50\% speak Batak, 25\% Javanese, $10 \%$ Mandarin, 5\% Nias, Sulawesi and Dutch, respectively with parents, siblings, aunts, uncles, cousins, and other relatives at 
home or during family gatherings. Another $5 \%$ speak more than two languages: Batak and Sundanese, and Javanese and Manado (vide Fig. 2).

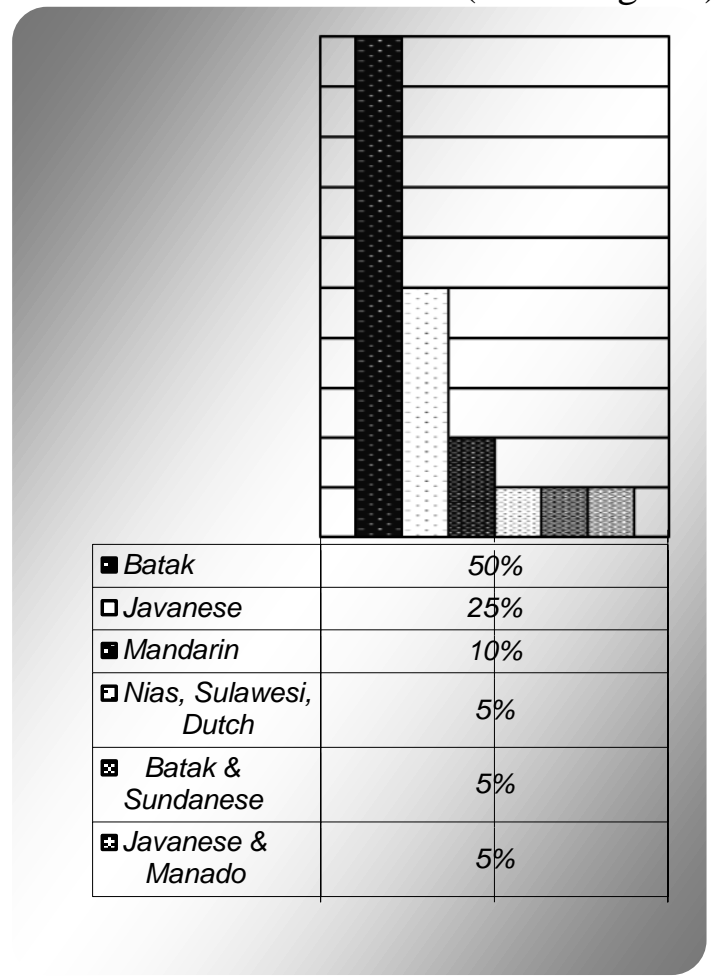

Fig. 2 Bilingual students' spoken languages at home

The bilingual students may be categorized into simultaneous early bilinguality in which they acquired the local language(s) that their parents speak and the BetawiMalay dialect. Yet, the monolinguals may be classified into consecutive childhood bilinguality as they were able to speak the Betawi-Malay dialect first before learning English (Hamers and Blanc 2000, pp.2829). However, school $X$ cannot be considered to conduct a bilingual education (Hamers and Blanc 2000, p.321) because they used Indonesian solely; English is merely used when it is taught at class.

It is interesting to note that although the monolinguals stated that they use Indonesian daily, $52 \%$ of the pupils use English between 11 to 15 hours a week, $48 \%$ between 1 to 5 hours, $19 \%$ from 6 to 10 hours, and another 19\% for more than 15 hours a week (vide Fig. 3) for activities like formal and non-formal learning
English at school, and English courses, respectively. Other activities that enable students to have contact with English include listening to and singing English songs, playing computer games, chatting on Twitter, and or watching English films (films that use English) (vide Fig. 4). Moreover, with regard to their language attitude towards Indonesian and English, $71 \%$ of the pupils stated that they were proud to be able to speak both Indonesian and English, 19\% were proud to speak English better than Indonesian, and the rest were proud of their ability to speak only Indonesian.

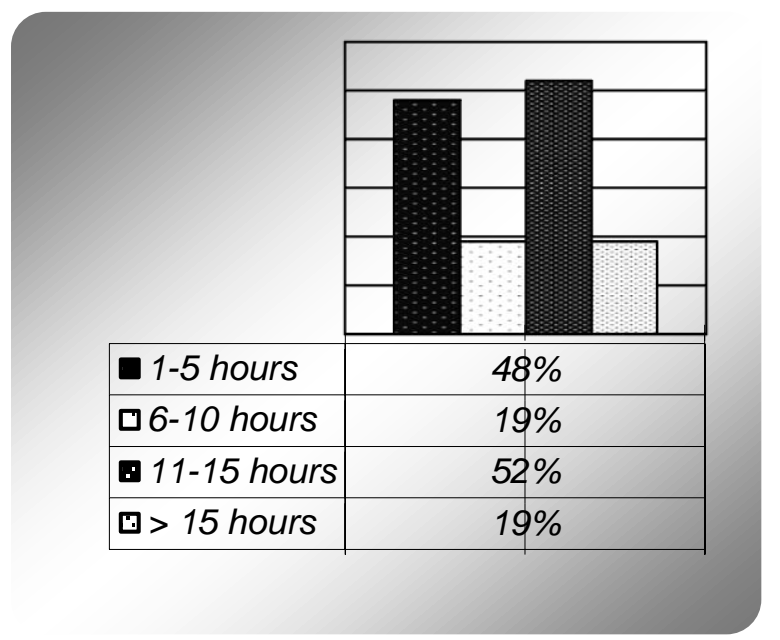

Fig. 3 Frequency of monolinguals' contact with English on a weekly basis

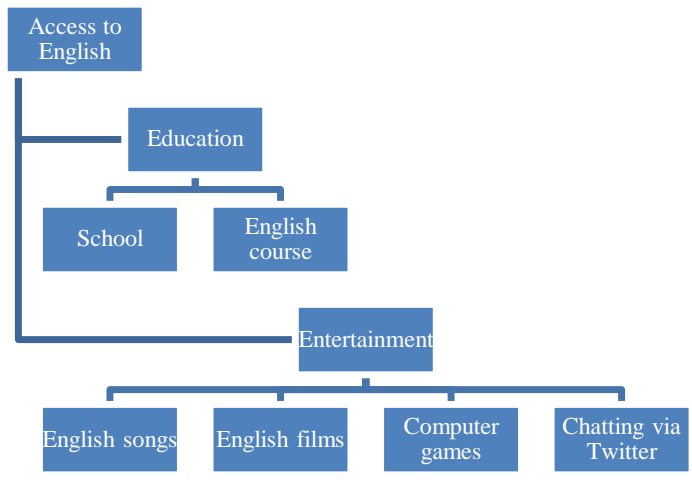

Fig. 4 Types of monolinguals and bilinguals' access to English 
On the other hand, the bilinguals appeared to have more contact with English compared to their monolingual classmates. On a weekly basis $32 \%$ of them used English between 1 to 5 hours, $13 \%$ from $6-10$ hours, $23 \%$ from 11 to 15 hours, and $32 \%$ over 15 hours (vide Fig. 5). The activities for which they used English was likely to be the same as those of the monolinguals', however much more hours were devoted to watch the cable TV programs such as Disney Channel, Cartoon Network, HBO Family, Nickleodeon, and $B B C$. One student, Bob (not a real name), stated that he often attended services in English and the other student, Alice (not a real name), had relatives in Australia so they used English to communicate. In general the monolinguals had more frequent contact with English.

The test of scanning skills showed that the monolinguals outperformed the bilinguals. The average score of the monolinguals were 74 , while the bilinguals 66 . However, the monolinguals outperformed the bilinguals in only the first part of the test. The total score for the first part of the text was 16; the monolinguals' average score was 12 , whereas the bilinguals' was 10 . Meanwhile, the total score for the second part was 10, and both the monolinguals' and bilinguals' average scores were 7 .

The finding may support research by Aquino (2012) which indicated that monolinguals were better than bilinguals. Using Indonesian as the only language spoken both at school and at home supports the monolinguals' scanning skill acquisition. Interestingly, as shown in Fig. 3 and Fig. 5, the monolinguals appeared to have more frequent contact with English texts than the bilinguals. Perhaps the access to English has made them outperform the bilinguals in the scanning test. Further research with a more complex instrument is needed to prove that.

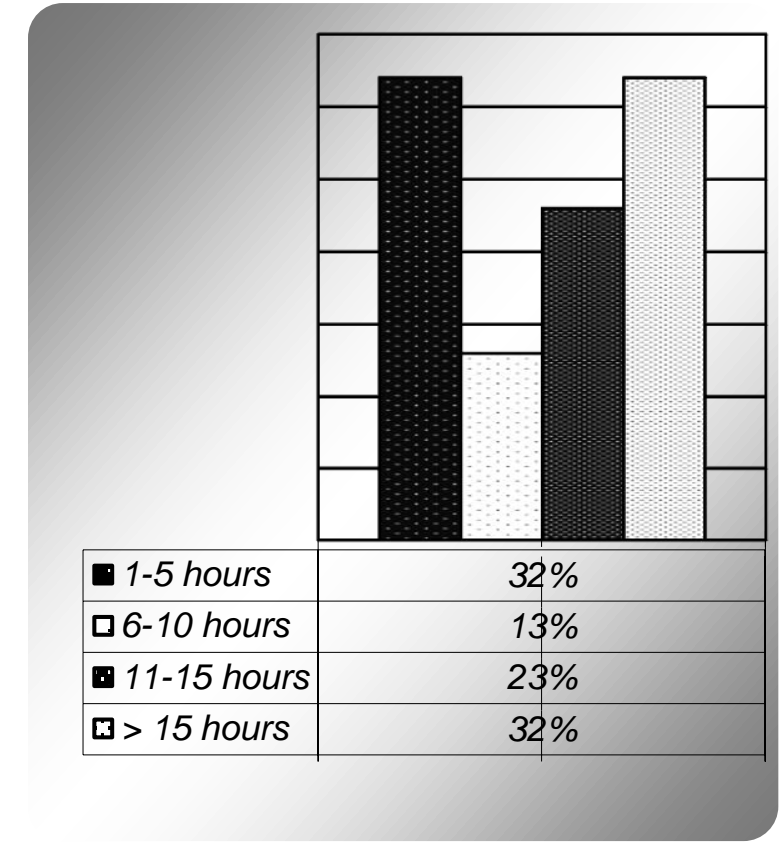

Fig. 5 Frequency of bilinguals' contact with English on a weekly basis

Meanwhile, the first part of the test required the participants to complete a table containing information on previous and recent jobs, the duration, and reasons for choosing the job (for complete details about the test see Method section and Appendix 2). Although many of the participants, be they bilinguals or monolinguals made typical mistakes when completing the second and third columns, titled Job before and Job now, respectively, fewer monolinguals (48\%) made mistakes on this area compared to their bilingual counterparts $(59 \%)$. They wrote recent jobs for the Job before column, and previous jobs for the Job now column. I suspected there were several reasons for the previously mentioned mistakes: (1) not knowing the meanings of before and now; (2) ignorance or lack of knowledge on the use of past tense that marked the previous jobs, and the use of present tense for stating the recent jobs; (3) lack of vocabulary knowledge, and (4) not understanding the instruction.

In the second part most students made mistakes in finding specific information about 'climate' (vide Appendix 2 Part 2). Then, $78 \%$ of the bilinguals and $73 \%$ of 
the monolinguals filled in the information on 'climate' with average rainfall, which was actually the expression that came after the word climate in the text. I assumed that the cause might be either the students did not know the meaning of the word climate, or did not have any background knowledge on geographical terms used in the text.

\section{CONCLUSION}

In this article I have exemplified how Indonesian young learners in general are more exposed to English through increasing contact with foreigners from the English speaking countries that the occurrences of code mixing and switching, and the desires of learning English at schools and courses are now higher than that in the past. Yet, the fact has not automatically made English becomes a second language. It still remains a third, maybe fourth language learned, not acquired, by most Indonesians. Up to now, English is still an optional subject, the teaching of which is dependent largely on the school's funding. I have also stated that another crucial factor that should be taken into account in a learning process is the reading habit or culture, which is not highly appreciated in Indonesia. It is in such circumstance was I interested to find out whether the increasing access to English has produced important effect for the learning of English reading skills, particularly reading skills. The small research I conducted showed that the monolingual Indonesians had better scores compared to their bilingual counterparts. Unquestionably further investigation especially in figuring out why the monolinguals were able to outperform the bilinguals in terms of the scanning skills is needed. The present study cannot be said to represent the Indonesian bilinguals and monolinguals because of its limited scale and research instrument. Further research should also include an application of relevant statistical analysis of another standardized English reading test to a wider population, and another type of questionnaire.

\section{REFERENCES}

Aquino, L. F. Y. (2012). The effects of bilingual instruction on the literacy skills of young learners.ELTWorldOnline.com 4.pp.1-13. Retrieved from http://files.campus.edublogs.org/blog. nus.edu.sg/dist/7/112/files/2012/06/T he-Effects-of-Bilingual-Instructionon-the-Literacy-Skills-of-YoungLearners_editforpdf-1bamrk2.pdf [October 20, 2012]

Baker, C. (1992). Attitudes and language. Clevedon: Multilingual Matters.

Baker, C. (2001). Foundations of bilingual education and bilingualism.( $3^{\text {rd }} \mathrm{ed}$.). Clevedon: Multilingual Matters.

Bialystok, E. (2003). Bilingualism in development: Language, literacy and cognition. ( $3^{\text {rd }}$ ed.). Cambridge: Cambridge University Press.

Bloomfield, L. (1935). Language. London: George Allen \& Unwin Ltd.

Busch, M. (1993).Using Likert scales in L2 research - A researcher comments. TESOL Quarterly, 27(4), pp.732-736. Retrieved from http://lib.atmajaya.ac.id/Uploads/Fullt ext/146616/artikel/Michael\%20Busch .pdf [September 28, 2012]

Clarke, M.A. \& Silberstein, S. (1979).

Toward a realization of

psycholinguistic principles in the ESL reading class. In R. Mackay, B. Barkman, and R.R. Jordan. Reading in a second language: Hypotheses, organization and practice, pp.48-65. Massachusetts: Newbury.

Crystal, D. (2003). English as a global language. Cambridge: Cambridge University Press.

Djiwandono, P.I. (2005). Teach my children English: Why parents want English teaching for their children. eIndonesian Journal of English Language Teaching, 1(1), pp. 62-72. Retrieved from 
http://www.indonesianjelt.org/Pages/ BackIssueDetail.aspx?year $=2005 \& \mathrm{~m}$ onth $=5 \&$ volume $=1 \&$ edition $=1$ [October 11, 2012].

Djiwandono, P.I. (2009). Upaya mempelajari bahasa asing: sejauh mana dan mau kemana? e-Linguistik Indonesia,27(1), pp. 1-13. Retrieved from

http://www.indonesianjelt.org/Pages/ BackIssueDetail.aspx?year $=2005 \& \mathrm{~m}$ onth $=5 \&$ volume $=1 \&$ edition $=1$ [October 11, 2012].

Grabe, W. \& Stroller, F. L. (2002). Teaching and researching reading. Harlow: Pearson

Grabe, W. (2009).Reading in a second language: Moving from theory to practice. Cambridge: Cambridge.

Grosjean, F. (2010).Bilingualism: Life and reality. Cambridge: Harvard University Press.

Hamers, J. F. and Blanc, M.H.A. (2000).Bilinguality and Bilingualism. Cambridge: Cambridge University Press.

Heaney, N. (2005). Hubungan bahasabahasa di Malang: Pengaruh bahasa Inggris terhadap bahasa Indonesia pemuda. An ACICIS-Muhammadiyah University of Malang field research paper. Retrieved from http://www.acicis.murdoch.edu.au/hi/ field_topics/nickheaney.pdf [October $15,2012]$

Hudson, T. (2007).Teaching second language reading. Oxford: OxfordUniversity Press.

Kachru, Y. (2011). World Englishes: Contexts and relevance for language education. In Eli Hinkel (Ed).Handbook of research in second language teaching and learning, Volume II.pp.155-172. New York: Routledge.

Munby, J. (1978). Communicative syllabus design: A sociolinguistic model for defining the content of purpose-specific language programmes. Cambridge: Cambridge.
Nation, I.S.P. (2009). Teaching ESL/EFL reading and writing. New York: Routledge.

Nurkamto, J. (2003). Problema pengajaran Bahasa Inggris di Indonesia. $e$ -

Linguistik Indonesia 21 (2), 287-307. Retrieved from http://www.eli.org/Pages/BackIssueDetail.aspx?ye ar $=2003 \&$ month $=8 \&$ volume $=21 \&$ edi tion $=2$ [October 12, 2012]

Nuttal, C. (1996).Teaching reading skills in a foreign language. Oxford: Heinemann.

Progress in International Reading Literacy Study (PIRLS).(2006). Students' reading attitudes, self-concept, and out-of-school activities. Retrieved from http://timss.bc.edu/PDF/P06_IR_Ch4. pdf [November 17, 2012].

Rafiani, R. (2009). Indonesian-English code switching in teenagers magazine: A review of 10-year development. [Abstract] An unpublished master's thesis. Jakarta: Atma Jaya Catholic University of Indonesia. Retrieved from http://lib.atmajaya.ac.id/Uploads/Fullt ext/164768/List\%20of\%20Contentsfinal\%20revision.pdf [October 9 , 2012]

Ridley, N. D. (2005). The effects of bilingual education on reading test scores: Can dual-immersion support literacy for all students? An unpublished master's thesis. Texas: University of North Texas. Retrieved from http://digital.library.unt.edu/ark:/6753 1/metadc4751/m2/1/high_res_d/thesis .pdf [October 20, 2012]

Romaine, S. (1989,1985). Bilingulism (2nd Ed.). Oxford: Blackwell Publishers.

Sari, F. (2010). Parent-teacher attitudes toward bilingual education program in Indonesia. A paper presented to the $20^{\text {th }}$ Linguistic Conference of Center for Language and Culture Studies. 
Atma Jaya Catholic University of Indonesia, Jakarta, October 5-6.

Siregar, F.L. (2010). The language attitudes of students of English literature and D3 English at Maranatha Christian university toward American English, British English, and Englishes in Southeast Asia, and their various contexts of use in Indonesia. Philippines ESL Journal 4, 66-92.Retrieved from http://www.philippine-esljournal.com/V4_A4.pdf [October 15, 2012]

Toloa, M. McNaughton, S. and M, Lai. (2009). Biliteracy and language development in Samoan bilingual classrooms: The effects of increasing English reading comprehension. International Journal of Bilingual Education and Bilingualism, 12(5), 513-531. Retrieved from http://content.ebscohost.com/pdf23_2 4/pdf/2009/GKS/01Sep09/44081534. pdf [November 16, 2012].

Turner, J. (1993). Using Likert scales in L2 research - Another researcher comments. TESOL Quarterly, 27(4)pp. 736-739. Retrieved from http://lib.atmajaya.ac.id/Uploads/Fullt
ext/146616/artikel/Jean\%20Turner.pd f [September 28, 2012]

Underwood, G. \&Batt, V. (1996).Reading and understanding: An introduction to the psychology of reading. Oxford: Blackwell.

Weinreich, U. (1963). Languages in contact: Findings and problems. The Hague: Mouton \& Co.

Weir, C. (1993).Understanding and developing language test. New York: Prentice Hall.

Wiradisastra, G. (2006). A preliminary study of code switching in the speech of an Indonesian English bilingual.Indonesian Journal of English Language Teaching2(2), pp. 195-211. Retrieved from http://lib.atmajaya.ac.id/Uploads/Fullt ext/123874/artikel/Grace\%20Wiradis astra.pdf [October 9, 2012]

Zacharias, N.T. (2010). Issues of TEYL in Indonesian and what parent can do about it. e- Indonesian Journal of English Language Teaching,6(2), pp. 75-88. Retrieved from http://www.indonesianjelt.org/Pages/ BackIssueDetail.aspx?year $=2010 \& \mathrm{~m}$ onth $=10 \&$ volume $=6 \&$ edition $=2$ [Octo ber 9,2012$]$. 


\section{Appendix 1. Survey open-ended questions}

\section{Jawablah pertanyaan berikut ini.}

1. Bahasaapa yang kamugunakansehari-hari?

2. Apakahkamujugamenggunakanbahasadaerah? Bilaya, silahkanmenjawabpertanyaannomor 3.

3. A. Bahasadaerahapa yang kamugunakan?

B. Dengan siapa kamu berbicara bahasa daerah tersebut?

C. Dalam kegiatan apa kamu berbicara bahasa daerah tersebut?

4. A. Dengan siapa saja kamu berbahasa Indonesia?

B. Dalam kegiatan apa saja kamu berbahasa Indonesia? (Sebutkansesuaikenyataannya)

5. A. Kuranglebihberapa jam dalamseminggumenggunakanbahasaInggris? (contohkegiatanberbahasaInggris. mendengarkanlaguberbahasaInggris, berbicaradengantemanmemakaiBahasaInggris, chatting di Facebook, Twitter dll. MenggunakanBahasaInggris, bernyanyidenganBahasaInggris, dan lain-lain sesuaidengankenyataannya) jam / minggu

B. DalamkegiatanapasajakamuberbahasaInggris? (Sebutkansesuaikenyataannya)

C. DengansiapasajakamuberbahasaInggris? (Sebutkansesuaikenyataannya)

6. A. Manakah yang lebihkamusukai, bahasaIndonesia,bahasaInggrisataukeduanya?

Mengapa?

B. Menurutmu, manakah yang lebihpenting, bahasa Indonesia,
bahasaInggrisataukeduanya?.
Mengapa?

C. Menurutmu, manakah yang lebihmembuatmubangga, bisaberbahasa Indonesia saja, biasberbahasaInggrissaja, ataubiaskeduanya?

Mengapa?

Umur:

TahunKelas:

SD

Jeniskelamin:

Namalengkap: 
Appendix 2.Questions for test of scanning skill (Weir 1993, pp.82-83, 85-86)

Part 1. Fill in the missing details on these people. The first details about Laila are done for you as an example.

Laila was once a policewoman but now she teaches young students because she likes children. She has taught for five years at the same school. Alice was also a teacher, but for two years she has worked as a reporter for Indonesian Television because she makes more money there. Ali works for Indonesian Television also as a presenter. He was a famous footballer but he injured his leg. He has presented the sports programme for the last three years. Anthony has been a photographer for two years. He was a farmer but all his cattle died in a great flood. Matthew works with Anthony. He's been in the job for four years. He was also a farmer, but he wanted a more interesting job.

\begin{tabular}{|l|l|l|l|l|}
\hline Name & Job before & Job now & Years & Why in job \\
\hline Laila & policewoman & teacher & 5 & likes children \\
\hline Alice & & & & \\
\hline Ali & & & & \\
\hline Anthony & & & & \\
\hline Matthew & & & & \\
\hline
\end{tabular}

Part 2. Read the description of Saudi Arabia below and complete the table. The first one has been done for you as an example.

Saudi Arabia is a Kingdom in the Arab Peninsula. More than six million people live there, mainly in the capital Riyadh and in the cities of Dhahran and Jeddah. The area of the country is approximately 450,000 square kilometers, which is mostly desert. The head of state is a member of the Royal family who is called King Fahd. The people who live there are called Saudis. They speak Arabic. Their official religion is Islam. The important Islamic Holy Places of Mecca and Medina are in the western part of Saudi Arabia. The currency, the money which the Saudis use, is the Riyal. The weather is nearly always hot. It has a desert climate with an average rainfall of about three inches although in some years it has been as high as seven inches. It produces exports mainly oil and some dates.

Country Saudi Arabia

Capital city

Area

Head of State

Official religion

Language

Currency used

Holy places

Exports

Climate

Average yearly rainfall 